\title{
Environmental Analysis Impact Reduction from Replacing a Traditional Mortar with an Earth-Fiber Plaster
}

\author{
Laura C. Moreno-Chimely ${ }^{1}$, M. Teresa. Sánchez-Medrano ${ }^{2}$, Yolanda G. Aranda-Jiménez ${ }^{1}$, \\ Eduardo Arvizu-Sanchez ${ }^{1}$, Kenya Suarez-Dominguez ${ }^{2, *}$, Edgardo J. Suarez-Dominguez ${ }^{2}$ \\ ${ }^{1}$ Faculty of Architecture, Design and Urbanism, Autonomous University of Tamaulipas, South Centre, Tampico, Tamaulipas, Mexico \\ ${ }^{2}$ FADU Research Centre, UAT, Circuito Universitario, CUS, Tampico, Tamaulipas, Mexico
}

Received July 11, 2021; Revised September 15, 2021; Accepted October 17, 2021

\section{Cite This Paper in the following Citation Styles}

(a): [1] Laura C. Moreno-Chimely, M. Teresa. Sánchez-Medrano, Yolanda G. Aranda-Jiménez, Eduardo Arvizu-Sanchez, Kenya Suarez-Dominguez, Edgardo J. Suarez-Dominguez, "Environmental Analysis Impact Reduction from Replacing a Traditional Mortar with an Earth-Fiber Plaster," Environment and Ecology Research, Vol. 9, No. 5, pp. 282 - 299, 2021. DOI: 10.13189/eer.2021.090508.

(b): Laura C. Moreno-Chimely, M. Teresa. Sánchez-Medrano, Yolanda G. Aranda-Jiménez, Eduardo Arvizu-Sanchez, Kenya Suarez-Dominguez, Edgardo J. Suarez-Dominguez (2021). Environmental Analysis Impact Reduction from Replacing a Traditional Mortar with an Earth-Fiber Plaster. Environment and Ecology Research, 9(5), 282 - 299. DOI: 10.13189/eer.2021.090508.

Copyright $\bigcirc 2021$ by authors, all rights reserved. Authors agree that this article remains permanently open access under the terms of the Creative Commons Attribution License 4.0 International License

\begin{abstract}
Mortars based on cement and sand are common in buildings; however, cement is characterized by consuming large amounts of energy. It is stated that there is possibility of reducing emissions to the environment if soil-based mixtures are obtained from the land near the house where they are used, but this is not generally demonstrated through a functional life cycle analysis. The life cycle analysis is carried out "from the cradle to the grave." In this research, we analyzed the environmental impact of materials used in earth-buildings in Mexico, which are typical in rural houses; three coatings cases were used: one traditional cement-sand, a second based on Earth with lime and fiber, considering that it is transferred manually from the surrounding soil, and another modifying the transfer but with industrial machinery. The fiber was produced from Agave lechuguilla torrey, a plant grown in the same field of housing location; the experimental part was developed at Tampico, Tamaulipas, Mexico, to obtain the selected composition and coating thickness. The results show that the impact on the environment and climate change can be reduced by up to $65 \%$. Using transport processes with fossil fuel-based equipment considerably increases the impact, so nearby material collection areas should be
\end{abstract}

considered to reduce environmental impact effectively.

Keywords Life Cycle Analysis, Sustainable Earth Mortar, Ecological Plaster

\section{Introduction}

Carbon footprint is generally associated with the greenhouse gases emitted into the atmosphere and products of producing or consuming goods and services [1]. However, there is disagreement concerning the selected emissions for the calculations. Some methodologies have been developed, but there is controversy in the final calculation [2] since some authors indicate that the entire life cycle of the material should be included. In contrast, others are specific analyses, top-down and bottom-up methods; the latter is generally more used. However, it has been established that Earth's temperature increases as the emissions increase too. If the $\mathrm{CO}_{2}$ were to double, the temperature would increase from 1.5 to $4.5^{\circ} \mathrm{C}[3]$. 
Among some of the gases mentioned to consider are Carbon Dioxide, Methane, Nitrous Oxide, Carbon Tetrachloride, Methyl Bromide, Methyl Chloroform, Perfluorinated Compounds, Dimethylter, Methylene Chloride, Methyl Chloride, and Perfluoropolieters. There are four calculation methods of carbon footprint, which obtain data from life cycle analysis (LCA). Such methods are

- Greenhouse Gas Protocol,

- Carbon Balance, which considers the accounting of direct and indirect GHG emissions,

- Compound Method based on Financial Accounts

- and Publicly Available Specifications (PAS), which defines the emissions sources and their potential effects [4].

LCA is a methodology that quantifies the environmental impacts of products, processes, and services in an integral way, quantifying all stages from the cradle to the grave. Under ISO 14040 [5]. The so-called environmental impact is the sum of all the impacts that occur during the life cycle.

The carbon footprint impact is also called global warming by other authors and calculation programs such as SIMAPRO [6], given the increasing temperature of the Earth's atmosphere and oceans. It is also known as greenhouse gases (GHG).

Land use considers the effects of human activities, while eutrophication, the degree of contamination in water bodies by human intervention. Damage to the ozone layer is measured by adverse effects on agricultural productivity and is determined by 22 leading gases. The decrease in reserves and crude oil refers to fossil or mineral fuels; radiation considers the emissions of radioactive material that cause cancer. Photochemical smog refers to secondary pollutants from the burning of fuels and solvents that cause cancer. Ecotoxicity is measured by the percentage of species present in the environment suffering from toxic stress.

\section{Methods}

The elements that refer to each section are determined for the calculations, starting with the extraction. The case of mortars includes, for each of the components:
a) Machinery
b) Equipment used
c) Move to the site

For production:

d) Internal transfer

e) Preparation by mixing

f) Move to the site

g) Consideration of human resources (transport from housing to work)

Manual processes and directly related to human beings do not produce a positive energy consumption (their emissions are considered zero) according to the regulations indicated by SEMARNAT and other methods reported $[6,7]$.

For the life cycle analysis of the proposed material, a functional unit of $1 \mathrm{~m}^{2}$ of coating of both traditional and alternative materials for flattening the interior wall of housing using manual means for its elaboration and placement with a useful life of 30 years was considered.

For the selection of practical life, an aging test corresponding to the ASTM G154 cycle was performed using a Q Lab 2017-Equipment: Q.U.V./Spray. $1.5 \mathrm{~W} / \mathrm{m}^{2}$ Irradiance was performed with a UVA-340 Lamp during cycles of 8 hours a day for a week, recording the weight before and after and the surface modifications of the materials analyzed: traditional mortar and two coatings made with fiber and natural stabilizers. Indoor use was considered for all cases. Comparison between conventional and proposed mortars, it was observed a percentage error of $0.058 \%$. It is assumed that there was no significant difference between them. It has a similar life because the comparison sample has a minimum useful life of 30 years was the same consideration in the present study.

The reference flow was adjusted to 3 different coatings, the first cement-sand-water traditional mortar $(0.015 \mathrm{~m}$ thickness) and two more alternative mortar composed of clay soil-lime-sand-natural fiber ixtle-water same thickness. This paper considers the collection of materials with and without transport to the production site. Figure 1 shows the experimental space to corroborate the usability of the materials. Figure 2 shows the application material in a real house wall located in Tampico, Tamaulipas Mexico.

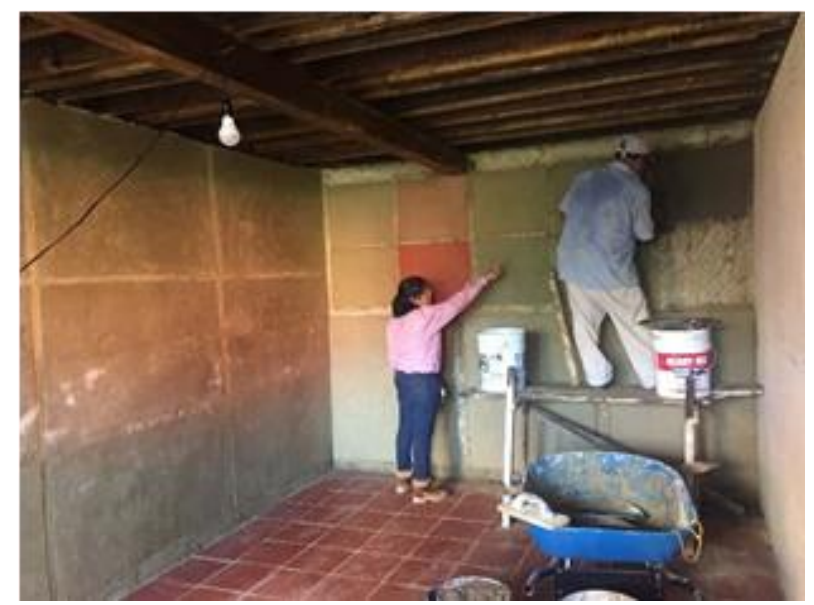

Figure 1. Image of earth test in walls

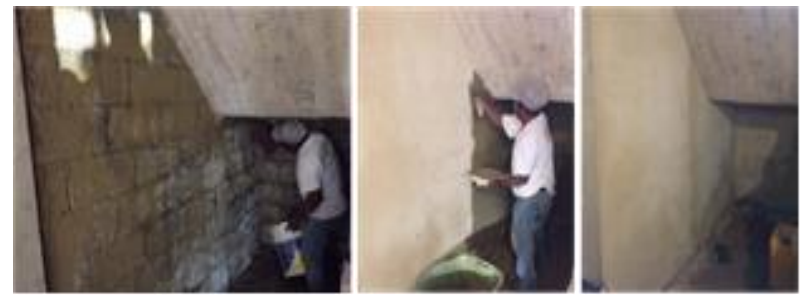

Figure 2. Image of earth mortar in walls surface 


\subsection{Functional Unit}

For analysis, we made an experimental plaster in Tampico Tamaulipas. For this, we analyze a build of $1 \mathrm{~m}^{2}$ coating with traditional and alternative materials for flattening the interior wall of housing using manual means for its elaboration and placement with a useful life of 30 years $[7,8]$.

\subsection{Reference Flow}

- REC-A Coating (A): $1 \mathrm{~m}^{2}$ of traditional coating mortar composed of cement-sand-water of $0.015 \mathrm{~m}$ thick, mixed and placed by hand with a metal trowel in the first level of housing.

- REC-B Coating (B): $1 \mathrm{~m}^{2}$ of alternative mortar coating composed of clay soil-lime-sand-natural fiber of ixtle-water $0.015 \mathrm{~m}$ thickness, mixed and placed by hand with a wooden trowel in the house's first level. The collection of materials with transport to the production site is considered.

- REC-C Coating (C): $1 \mathrm{~m}^{2}$ of alternative mortar coating composed of clay soil-lime-sand-natural fiber of ixtle-water of $0.015 \mathrm{~m}$ thick, mixed by hand and placed with a wooden trowel first level of housing. It is considered the collection of materials without transport to the site of production.

\subsection{System Limits}

A part of the life cycle shall be considered in the evaluation, from (CRADLE-TO-GRAVE):

Extraction of materials $\rightarrow$ Production $\rightarrow$ Use $\rightarrow$ End of life

Non-significant inputs such as the use of cutting equipment for vegetables that are not relevant will be disregarded. In this case, the Iso 14040 and 14044 standards will be met for the LCA.

The analysis has as temporality the year 2018-2019 and will be considered production in Tampico Tamaulipas, Mexico at coordinates 22.274411, -97.865297.
In Annex 1, it is shown the data used for calculation in each case, compound, and software considerations.

\subsection{Life Cycle Impact Assessment (IERIV.)}

The software used for the calculation of impacts was SimaPro 8.04.30. The characterization factors used for the different impact categories vary according to three different perspectives handled by the methodology. For $\mathrm{CO}_{2}$ parameters are established in [8].

Although there are other methods including the dimensions of the outcomes in the form of appreciation [9], the perspective used was the hierarchy $(\mathrm{H})$ with a time perception from a balance to long to short term and an evidence level of consensus-based inclusion, due to inclusion based on consensus [10,11].

As an additional element, the IPCC Method GWP 100 a was used to compare the carbon footprint emitted by the three reference flows.

The results obtained from the LCA process calculated with the CIMA-PRO software are presented:

- Part One: Comparison in stages (With ReCiPe Midpoint Method (H) V1.11 / World Recipe H and Endpoint $\mathrm{H}$ )

- REC-A, REC-B, and REC-C extraction

- Production REC-A, REC-B and REC-C

- Use REC-A, REC-B, and REC-C

- $\quad$ End of life REC-A, REC-B and REC-C

- Part Two: Life cycle comparison between coatings are called: REC-A, REC-B, and REC-C

\section{- Part Three: Carbon footprint}

Figure 3 shows all the steps in the life cycle analysis. First, we consider the extraction of raw materials for samples and the use of all the mortar compounds, and the production stage.

Distribution and use are also considered for a traditional house located in Tampico, Tamaulipas. End of life occurs after 30 years, which is the considered time for earthen construction with this system. 
LIFE CYCLE DIAGRAM

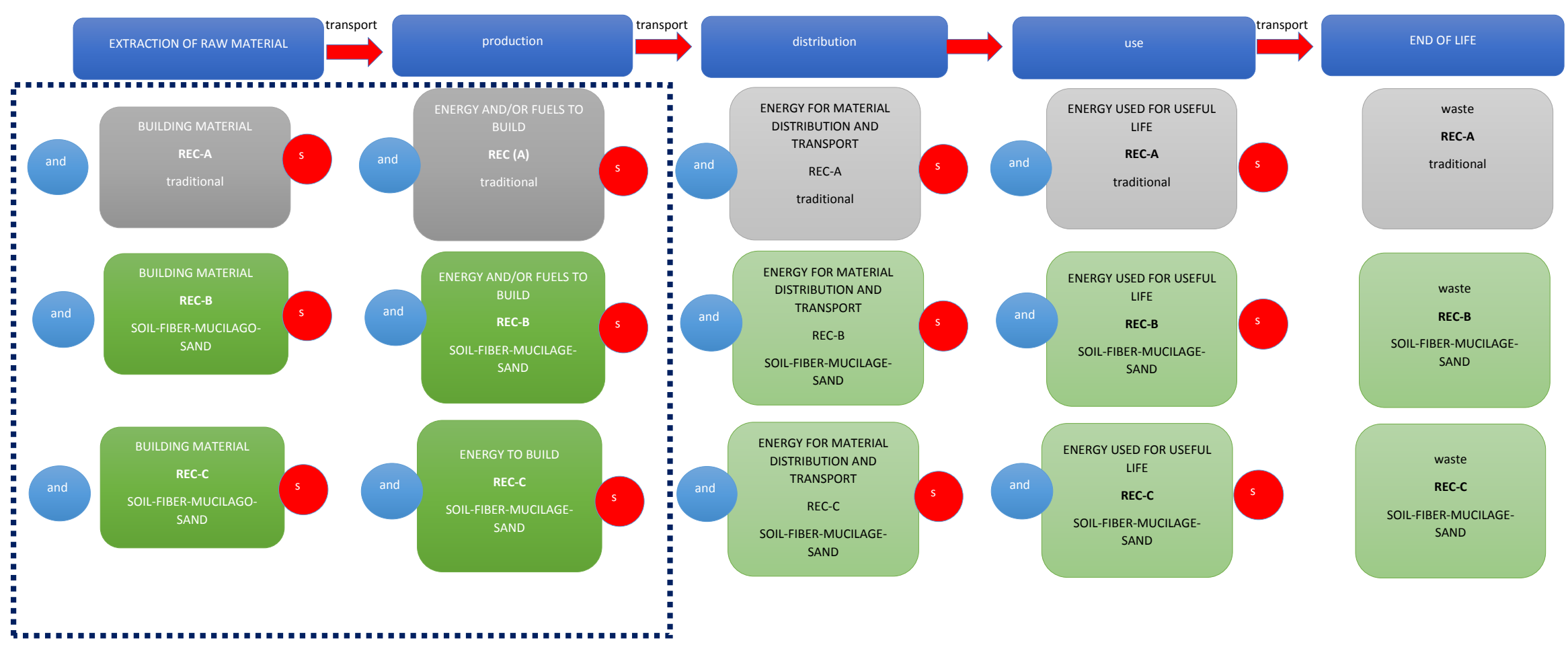

SYSTEM TO BE ANALYZED

Figure 3. Lifecycle diagram 


\section{Results}

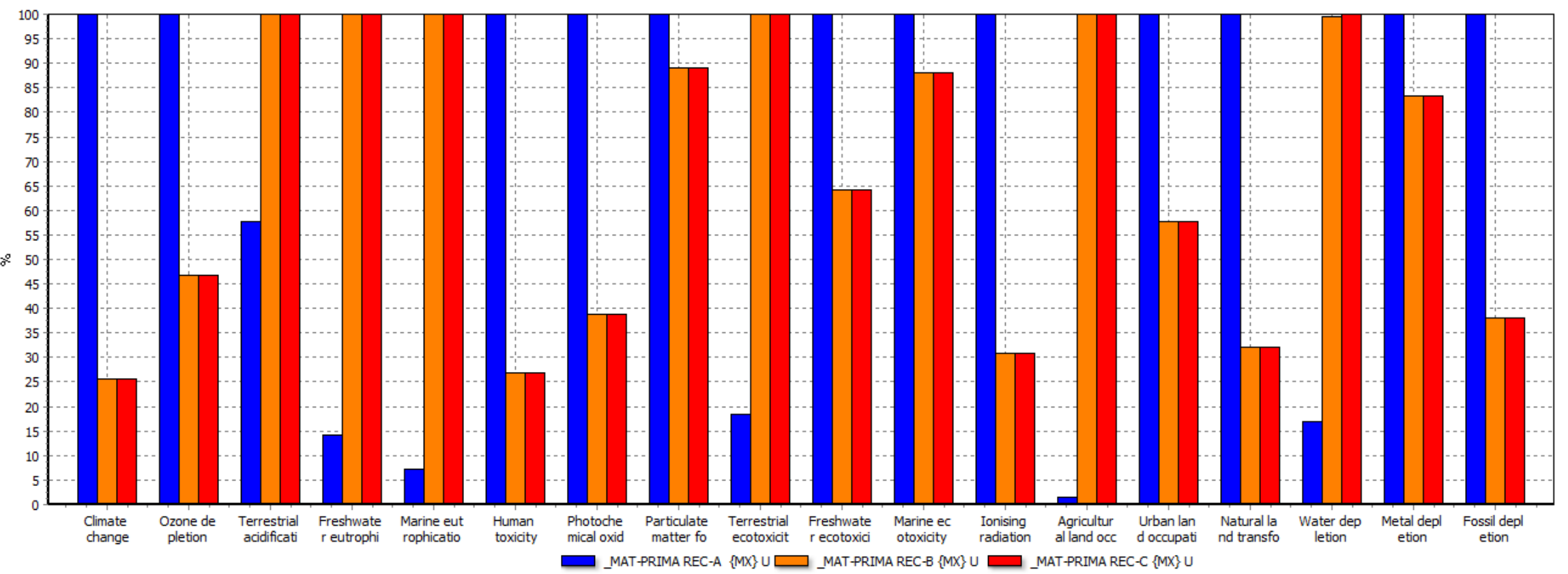

Comparando $31.5 \mathrm{~kg}$ '_MAT-PRIMA REC-A \{MX\} U', $11.5 \mathrm{~kg}$ '_MAT PRIMA REC-B \{MX\} U' y $11.5 \mathrm{~kg}$ '_MAT PRIMA REC-C \{MX\} U'; Método: ReCiPe Midpoint (H) V1.11 / World Recipe H / Caracterización / Excluyendo emisiones a largo plazo 


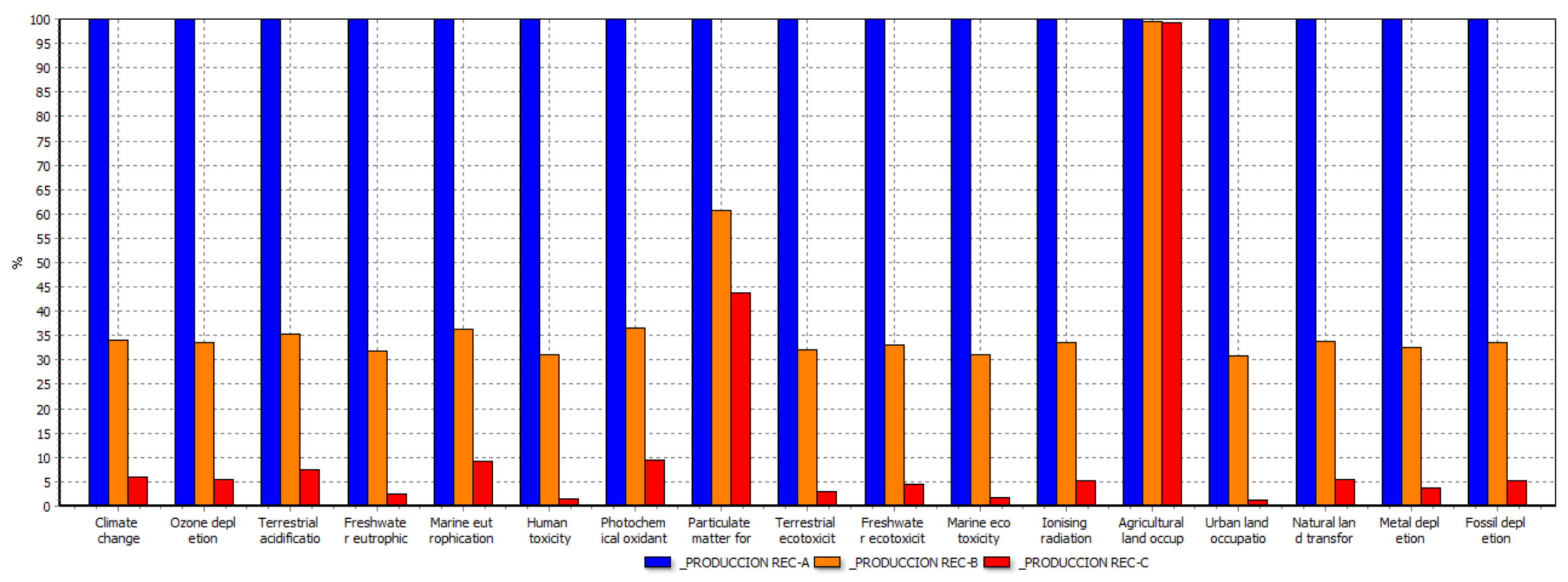

Comparando $1 \mathrm{~m} 2$ '_PRODUCCION REC-A', $1 \mathrm{~m} 2$ '_PRODUCCION REC-B' y $1 \mathrm{~m} 2$ '_PRODUCCION REC-C'; Método: ReCiPe Midpoint (H) V1.11/ World Recipe H / Caracterización / Exdluyendo emisiones a largo plazo 


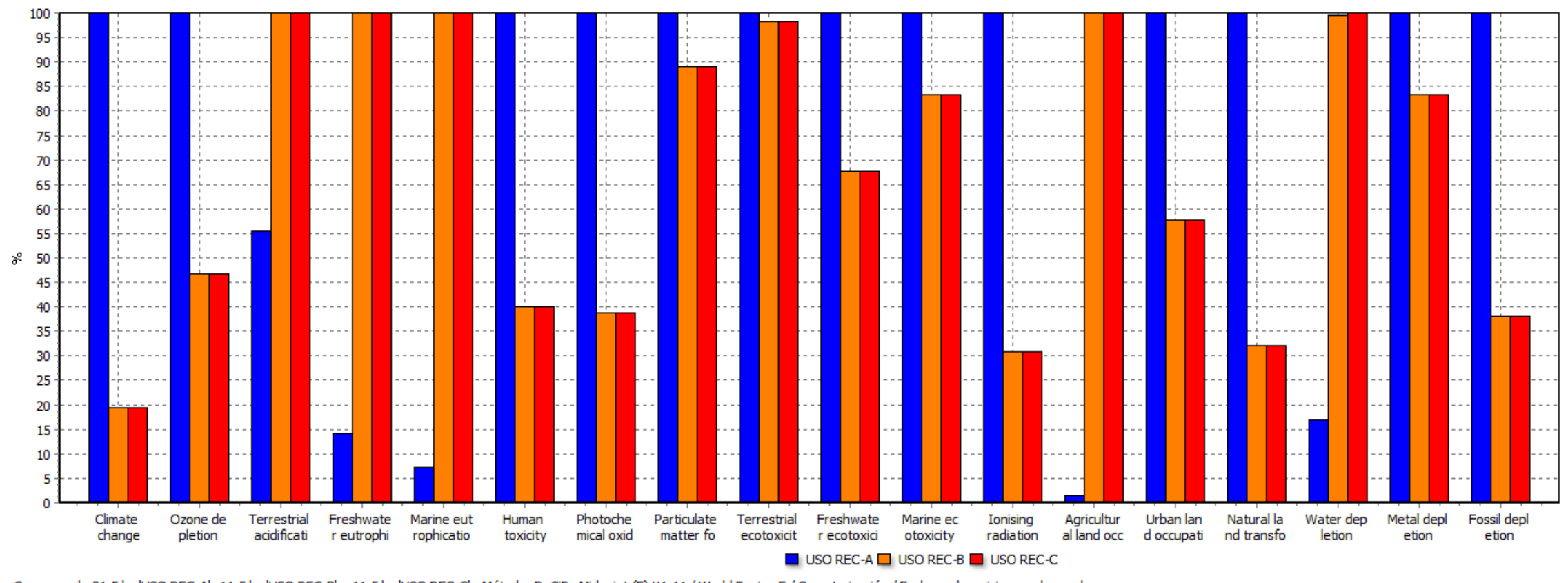

Comparando $31.5 \mathrm{~kg}$ 'USO REC-A', $11.5 \mathrm{~kg}$ 'USO REC-B' y 11.5 kg 'USO REC-C'; Método: ReCiPe Midpoint (E) V1.11 / World Recipe E / Caracterización / Excluyendo emisiones a largo plazo 


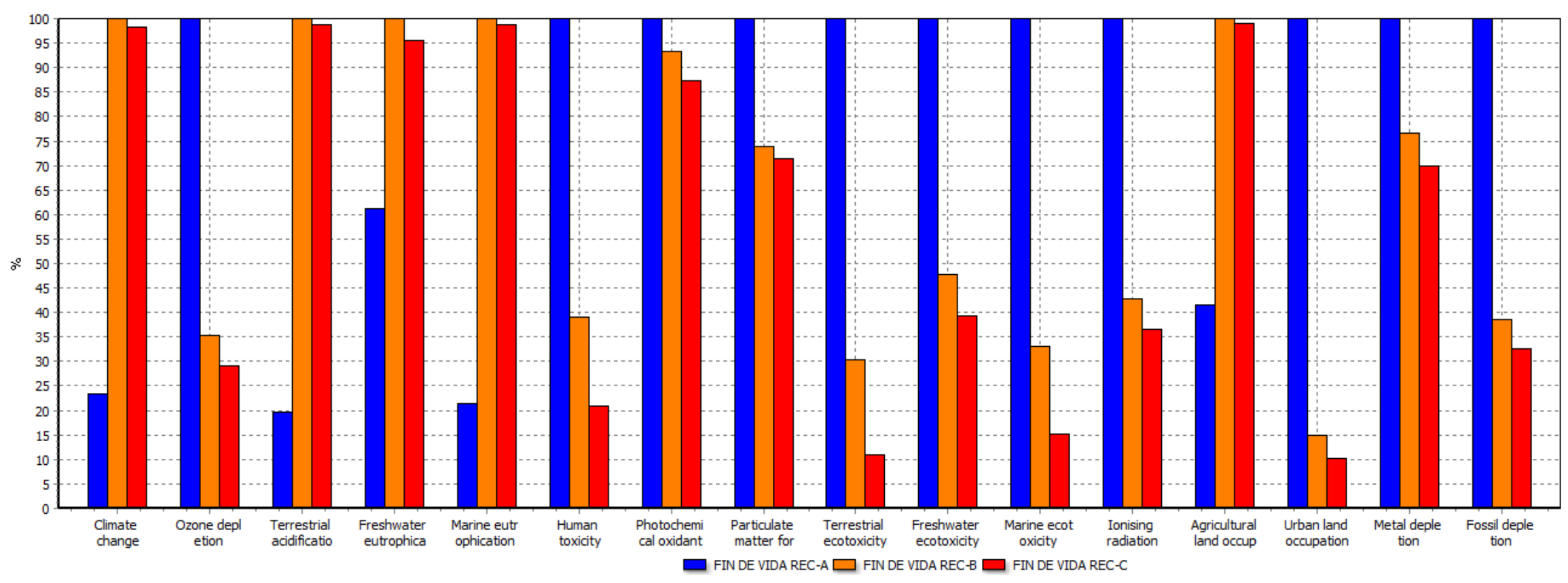

d)

Figure 4. Results for part 1: a). Characterization plot- Extraction, b) Characterization plot-Production, c) Characterization Plot-Use, and d) End-of-Life characterization plot. 


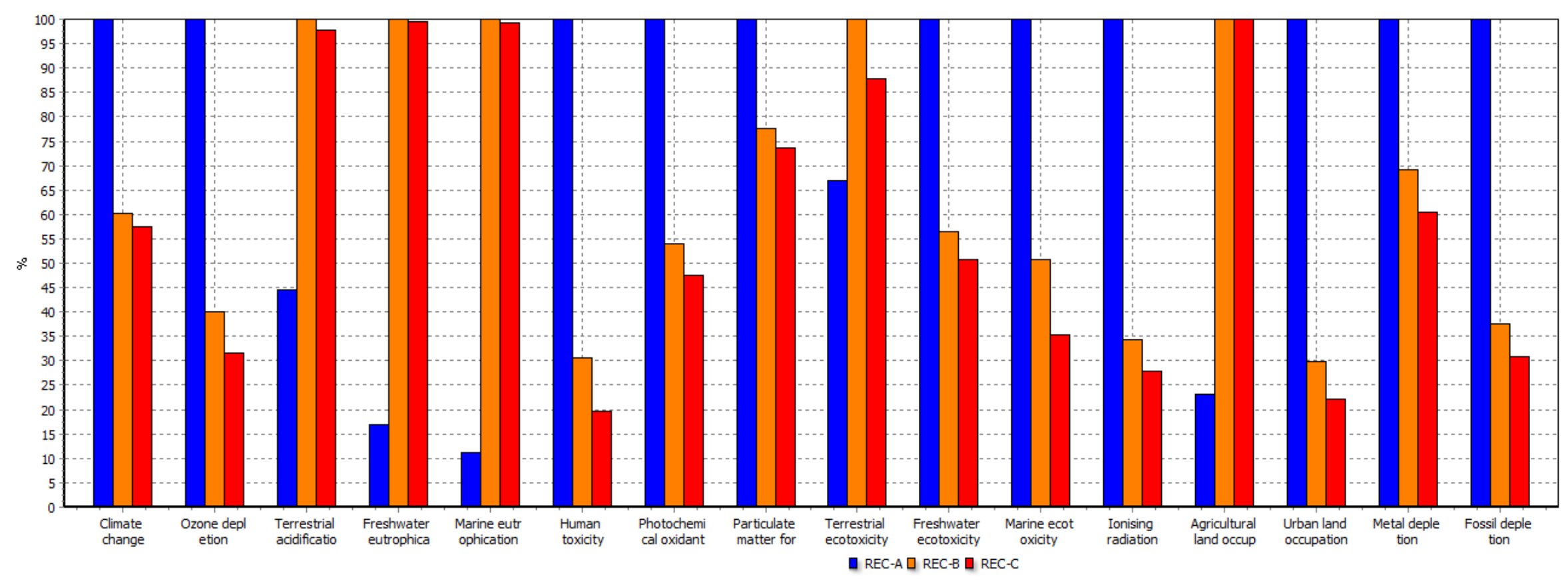




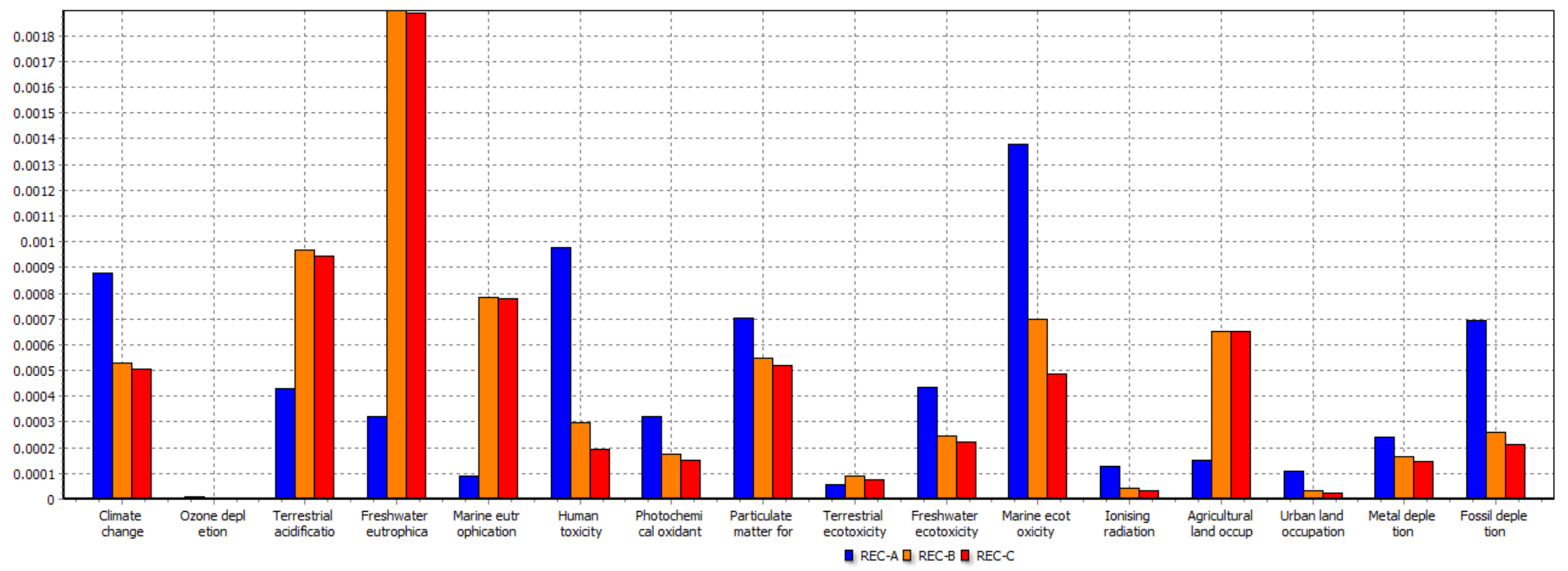




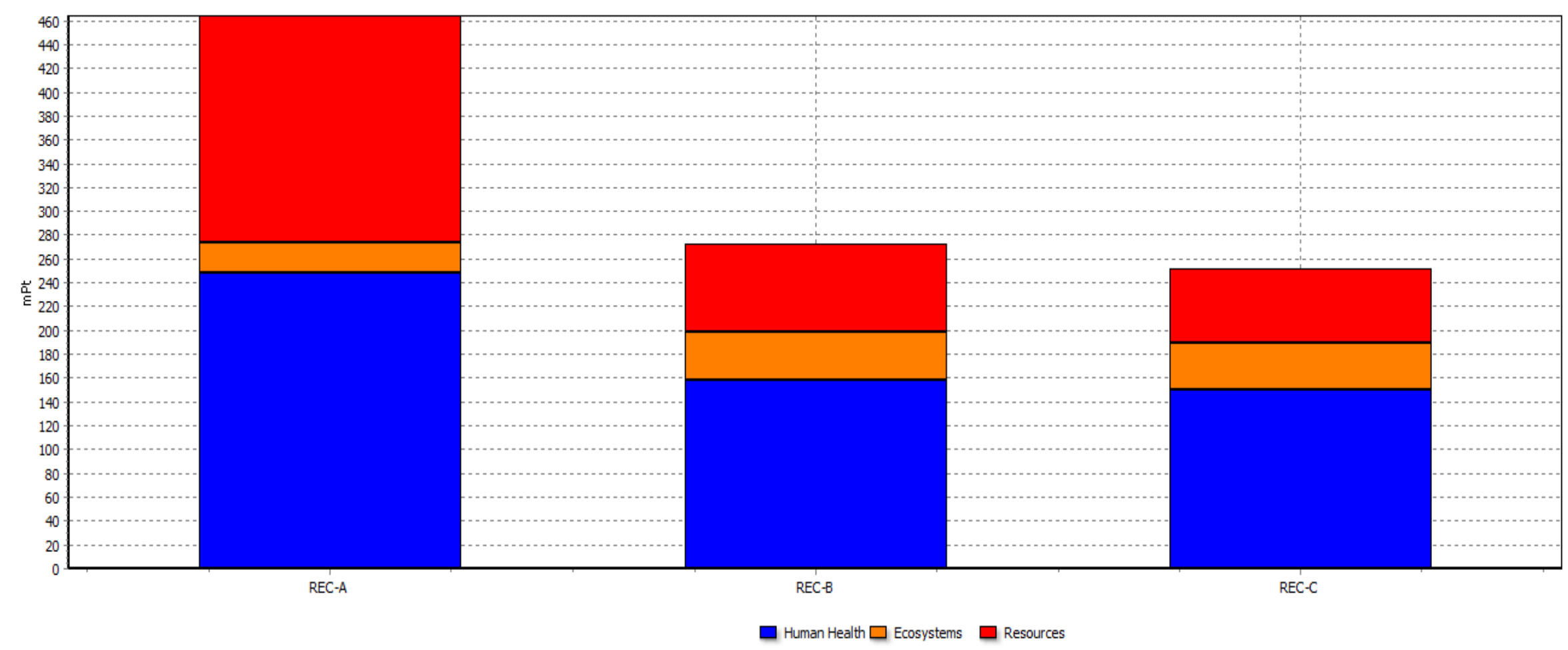

c)

Figure 5. Results for Part 2: a) Life cycle characterization-comparison plot, b) Normalization plot-life cycle comparison, and c) Normalization Plot -ReCiPe Endpoint LIFE CYCLE. 


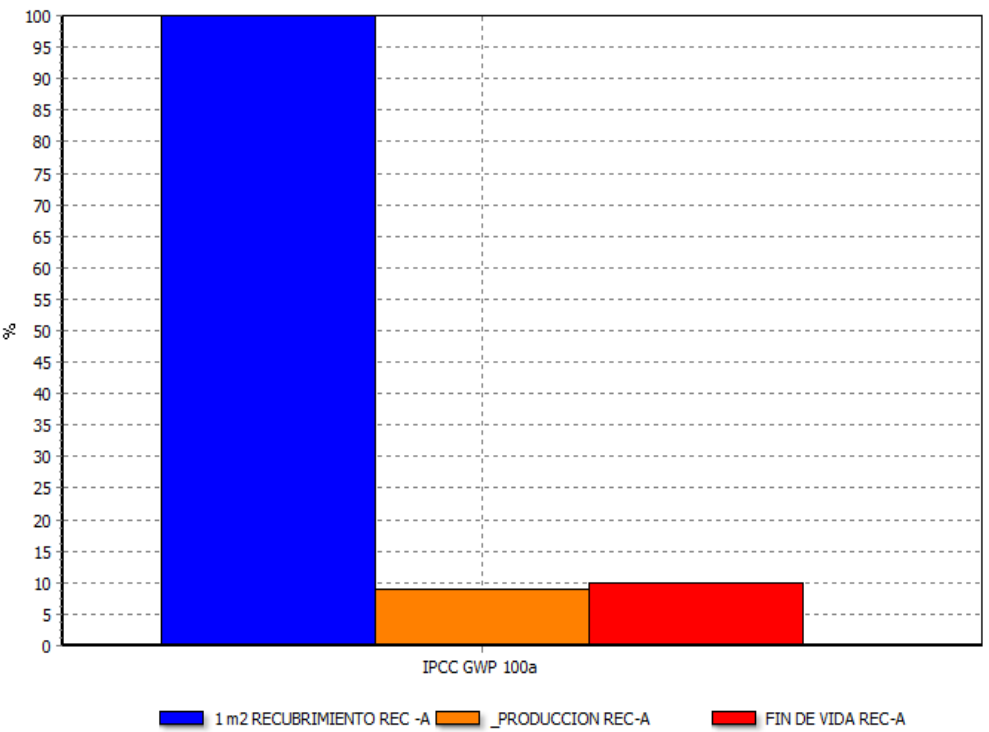

a)

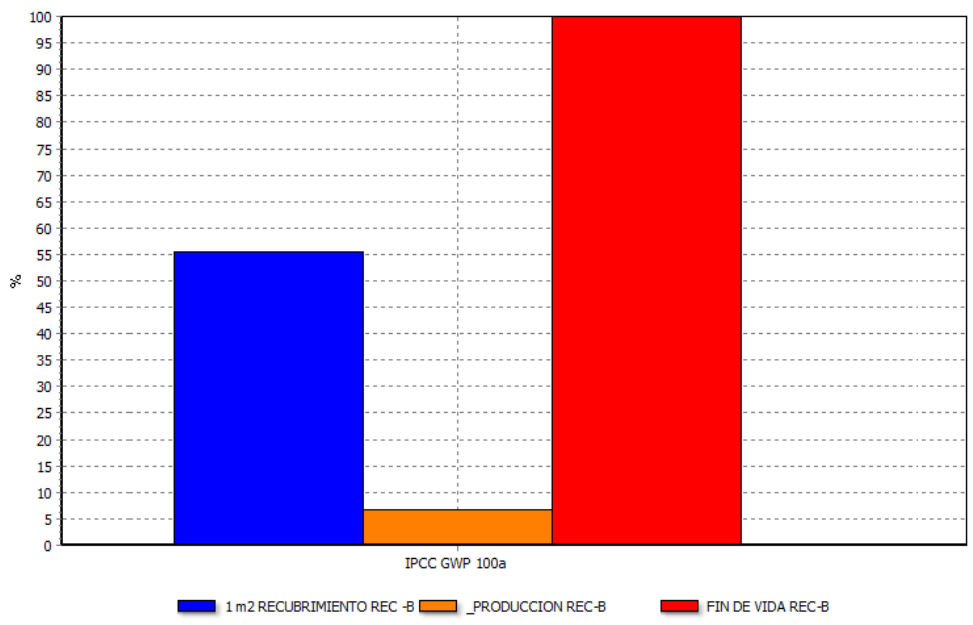

b)

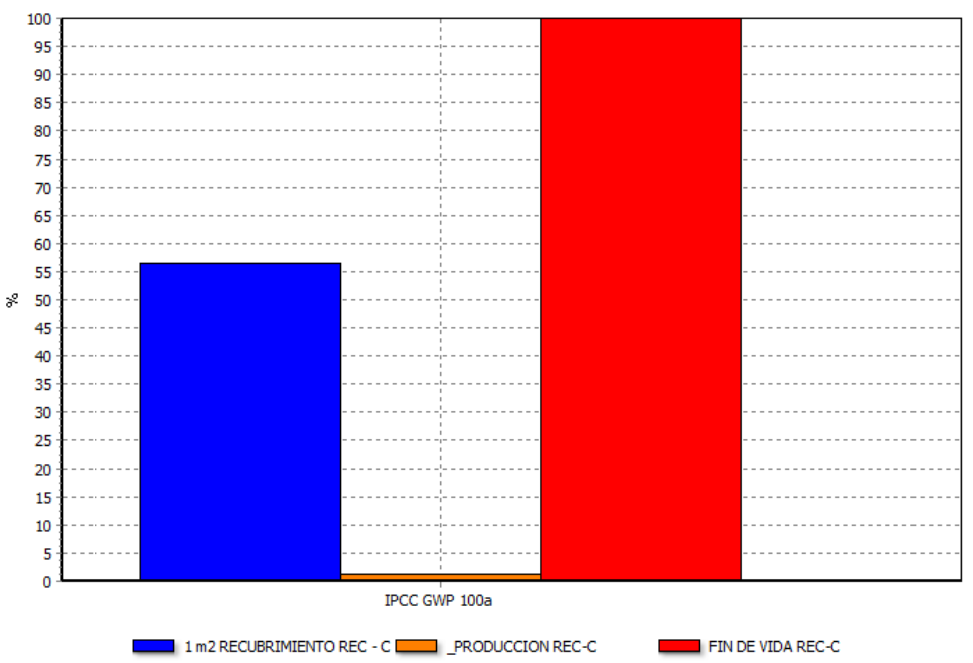

c)

Figure 6. a) Rec-A CARBON FOOTPRINT Calculation (IPCC GWP Method 100a), b) Rec-B carbon footprint calculation (IPCC Method GWP100a) and c) Rec-C carbon footprint calculation (IPCC Method GWP100 a) 


\section{Discussion}

There are many ways to enhance the use of materials and reduce emissions. For example, cement dosage optimization in concrete is a low-carbon way for similar resistance obtaining [12], but earth architecture is a more feasible alternative in many places in the world. This paper is focused on a specific material, and next, we discuss the three stages proposed in method about characterization comprising:

\section{First stage:}

Figure 4 shows the results for part 1 for REC-A, REC-B, and REC-C: a). Characterization plot-Extraction, b) Characterization plot- Production, c) Characterization Plot, d) End-of-LIFE characterization plot. For comparison of extraction stage for REC-A, REC-B, and REC-C coatings, REC-A presents a higher value in the damage categories, wherein climate change shows its highest value according to the characterization table 5.1 $\mathrm{kg} \mathrm{CO}_{2}$ eq.

REC-A sample is higher than REC-B and REC-C for Marine eutrophication, terrestrial ecotoxicity, and agriculture land occupation.

By integrating fewer materials into the inventory model for the REC-A, we have these results because the exploitation of sandbanks, clays, and limestones is reflected in the development.

In the graph of endpoints, the damages are grouped into three categories, with the damage to health to ecosystems and resources being the REC-A with the highest score, with the most significant potential impact.

The REC-A resulted in this comparison with the most significant impacts.

Production Stage Comparison for REC-A, REC-B, and REC-C coatings:

At this stage, the most significant potential impacts are presented again by REC-A, followed by $\mathrm{B}$, and finally REC-C, with impacts well below the first (REC-A).

The three coatings have very similar values for agriculture soil due to the apparent affectation of the sample used for this purpose.

The damage comparison can be seen in the Single Score Plot, where the REC-A containing cement reflects the most significant potential impact.

Stage-of-Use Comparison for REC-A, REC-B, and REC-C Coatings:

This stage does not reflect an expected value since the functional units related to construction are associated with the energies used to make the calculated product work. Here, they are not presented because they evaluate a single concept of what would correspond to a building.

If this material is in similar circumstances, concepts such as thermal conductivity capacity would be the ones that would give a reason for the effectiveness of each coating within a house.
As assumed when making the inventory models, the REC-C uses well-water to extract and produce the coating. All the extraction and material preparation is hand-made; this coating presents the best response by not charging the affectations from electrical energy use.

For this study, it has been assumed that the user with the same production conditions, eliminating the charges for transport so that the results expressed in the graphs of intermediate categories and endpoints are similar for the REC- B and C but lower than REC-A.

End-of-life stage comparison for REC-A, REC-B, and REC-C coatings:

For materials' final disposal, the inputs of REC-A go to the landfill, and those of REC-B and C are arranged to be used as compost for growing soils. Different impacts are observed between the three coatings, being again the REC-C presents except for three categories the most favorable response.

It can be observed that again the occupation of land for agriculture is affected in rec-B and $\mathrm{C}$ because effectively, the soil used does not return to its area of origin but is available elsewhere, and this is not integrated into the database.

Carbon FOOTPRINT comparison for Rec-A, Rec-B, and Rec-C coatings: The use stage has the most significant potential impact followed by extraction for all categories. Rec-B is the one that has the most significant impact on the calculation of the carbon footprint.

\section{Second stage:}

Figure 5 shows the results for Part 2: a) Life cycle characterization-comparison plot, b) Normalization plot-life cycle comparison and c) Normalization Plot-ReCiPe Endpoint LIFE CYCLE. Life cycle comparison between REC-A, REC-B, and REC-C coatings:

Analyzing the complete life cycle of each product and bringing it to contrast, $\mathrm{REC}-\mathrm{C}$ is rated better in 11 categories of the 16 evaluated and consistently below the Rec-B that considers transport in its extraction and production. Rec-A has the highest impact with $6.06 \mathrm{~kg}$ $\mathrm{CO}_{2}$ eq, resulting in $66 \%$ above $\mathrm{B}$ and $74 \% \mathrm{~A}$.

\section{Third stage:}

Figure 6 shows the results for carbon footprint; a) Rec-A CARBON FOOTPRINT Calculation (IPCC GWP Method 100a), b) Rec-B carbon footprint calculation (IPCC Method GWP100a) and c) Rec-C carbon footprint calculation (IPCC Method GWP100. For carbon footprint comparison between REC-A, REC-B, and REC-C coatings, we see that in the extraction of the material for REC-A, its largest carbon footprint is in the extraction stage, being approximately 11 times greater than the other stages.

In the case of REC-B, its most significant footprint is reflected in its final disposal by handling the material for 
use for composting. However, it is far below in the extraction stage of REC-A with $25 \%$ of its value.

In the case of REC-C, it is below REC-B and, in terms of extraction, also has approximately $25 \%$ of REC-A value. It is the production stage where the lowest result is observed With $0.0271 \mathrm{~kg} \mathrm{CO}$ eq, 17.5 of the rec-B value, and $6 \%$ of the rec-C value.

The used mortar has an apparent good finishing so that it can be helpful for all kinds of walls (Figure 7)

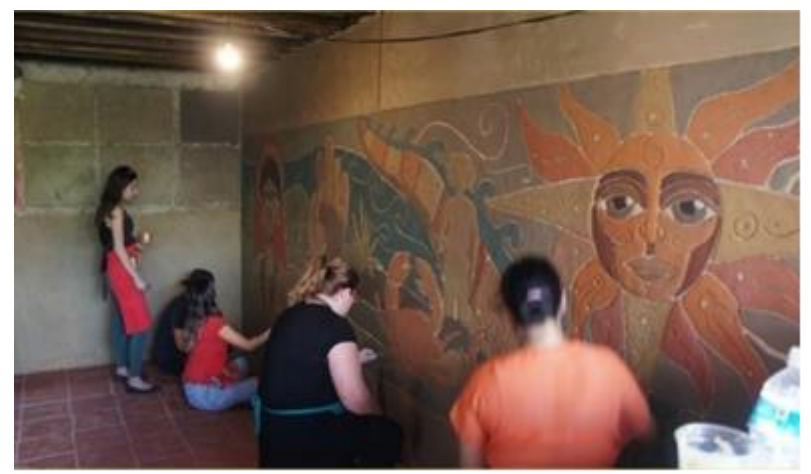

Figure 7. Finishing of the use of earth mortars in a wall

\section{Conclusions}

The comparison does not mean that one or the other coating is supported but that the geographical context and local conditions must influence decision-making. Obtaining products from the SimaPRO libraries database leads to global models that skew the information by containing different energies in inventory processes.

Therefore, the preparation of local life cycle inventories is recommended to eliminate the disparity in some values represented as potential damage impacts.

REC-C resulted in values below REC-A and B, where cement (REC-A) ultimately impacts all damage categories. Another value that affects the results obtained is transport, regardless of the material or construction system. If it has to be transported over long distances, it becomes undesirable for the impacts it entails, especially in the category of damage of climate change.

The analysis was carried out in three stages. In the first stage, the processes of extraction of materials, production, and use of the mortar. The end of life of the applied product was studied. The ordinary mortar presents a higher value in the categories of damage in the extraction, wherein climate change shows its highest value $5.1 \mathrm{~kg}$ $\mathrm{CO}_{2}$ eq. This same coating presents more significant damage to health, ecosystems, and resources. The three coatings have very similar values for agriculture soil due to the apparent affectation of the sample used for this purpose. The coating does not reflect an expected value since the functional units related to construction are associated with the energies used to make the calculated product work. Here, they are not presented because they are evaluating a single concept corresponding to a building. As for the final disposal of the materials, the alternative mortar coating with natural fiber without transport of materials is the one that presents except for three categories the most favorable response.

The second stage directly involves comparing the life cycle between the coatings. The one with the best rating is the one that contains natural fiber without transport of materials, having a positive score in 11 of the 16 categories evaluated. The coating with traditional mortar presents the most remarkable impacts with $6.06 \mathrm{~kg} \mathrm{CO}_{2} \mathrm{eq}$, resulting in $66 \%$ above the fiber coating with material transport and $74 \%$ above the one without material transport.

In the third stage comparison of the carbon footprint between coatings is made. During the material extraction for the ordinary mortar, the carbon footprint is 11 times greater than the other stages. For the coating with fiber and transport of materials, its most significant footprint is reflected in its final disposal by handling the material for composting. However, it is far below the extraction stage of the standard mortar coating with $25 \%$ of its value. For the coating with fiber and without transport of materials, this is below the coating with transport. In terms of extraction, it also has approximately $25 \%$ of the value of the REC-A mortar. It is the production stage where the lowest result is observed with $0.0271 \mathrm{~kg} \mathrm{CO}_{2}$ eq.

\section{Acknowledgments}

LCMC and YGAJ thank the Project supported by the Autonomous University of Tamaulipas for SNI members. MTSM Thanks to the CONACYT Project PN-2017-01-5975. This research was supported by CONACYT 2021 under Project 316443. 


\section{ANNEX}

\section{COATING A (REC-A)}

Information about materials obtaining for REC-A system and used in SIMAPRO software.

\begin{tabular}{|c|c|c|c|c|}
\hline $\begin{array}{l}\text { Materials obtaining for } \\
\text { REC-A }\end{array}$ & 1 & $\mathrm{~m}^{2}$ & $31.5 \mathrm{~kg}$ & \\
\hline Inputs & Amount & unit & Data & Database \\
\hline Sand & 18.56 & $\mathrm{~kg}$ & sand (RoW) gravel and query operation Alloc Rec, U & Ecoinvent 3 \\
\hline Cement & 5.55 & $\mathrm{~kg}$ & Cement, Portland (US) production Alloc Rec, U & Ecoinvent 3 \\
\hline $\begin{array}{l}\text { Diesel (Retroexcavadora) } \\
\text { para extracción de arena }\end{array}$ & 0.02 & MU & Energy, from diesel burned in machinery/R.E.R. Energy & Agri-footprint \\
\hline Water & 2 & $\mathrm{~kg}$ & $\begin{array}{l}\text { Tap water RoW tap water production, convectional treatment Alloc } \\
\text { Rec, } \mathrm{U}\end{array}$ & Ecoinvent 3 \\
\hline
\end{tabular}

\begin{tabular}{|c|c|c|c|c|c|c|}
\hline $\begin{array}{c}\text { Transport MAT } \\
\text { Production place } \\
\text { REC-A }\end{array}$ & 1 & \multicolumn{2}{|c|}{$\mathrm{m}^{2}$ REC-A } & & \\
\hline Inputs & Amount $(\mathrm{kg})$ & Distance $(\mathrm{km})$ & $\mathrm{tkm}$ & Capacity & Model Name & Data base \\
\hline Cement transport & 5.55 & 8 & 0.04 & 4 ton & $\begin{array}{c}\text { Transport, freight, lorry 3.5-7.5 metric ton, } \\
\text { Euro3 (RER) transport, freight lorry3.5-7.5 } \\
\text { metric ton, EURO3 Alloc Rec, U }\end{array}$ & $\begin{array}{c}\text { Ecoinvent } \\
3.0\end{array}$ \\
\hline Sand transport & 18.56 & 42 & 0.78 & 11 ton & $\begin{array}{c}\text { Transport, freight, lorry 3.5-7.5 metric ton, } \\
\text { Euro3 (RER) transport, freight lorry3.5-7.5 } \\
\text { metric ton, EURO3 Alloc Rec, U }\end{array}$ & $\begin{array}{c}\text { Ecoinvent } \\
3.0\end{array}$ \\
\hline
\end{tabular}

24.11

0.8239

\begin{tabular}{|c|c|c|c|c|}
\hline REC-A Elaboration & 1 & $\mathrm{~m} 2$ & & \\
\hline Inputs & Amount & Unit & Data Selection & Database \\
\hline $\begin{array}{l}\text { Materials transport } \\
\quad(0.02411 \mathrm{t})\end{array}$ & 823.9 & kgkm & $\begin{array}{c}\text { Transport, freight, lorry 3.5-7.5 metric ton, EURO3 } \\
\text { (RER.) Transport, freight, lorry 3.5-7.5 metric ton, } \\
\text { EURO3 (RER.) Alloc Rec, U }\end{array}$ & Ecoinvent 3 \\
\hline $\begin{array}{l}\text { Pine Wood 3th. For } \\
\text { scaffolding, any } \\
\text { level }\end{array}$ & 0.000122706 & $\mathrm{~m} 3$ & $\begin{array}{l}\text { Roundwood, Parana pine from sustainable forest } \\
\text { management, under bark (Row) softwood forestry, Parana } \\
\text { pine, sustainable forest management Alloc Rec, u }\end{array}$ & Ecoinvent 3 \\
\hline
\end{tabular}

\begin{tabular}{|c|c|c|c|c|c|}
\hline $\begin{array}{c}\text { Use } \| \text { REC-A } \\
\text { Wallcovering } \\
30 \text { years }\end{array}$ & 1 & $\mathrm{~m}^{2}$ & & & \\
\hline Inputs & Amount & Unity & \multicolumn{2}{|l|}{ Data selection } & Database \\
\hline $1 \mathrm{~m}^{2}$ covering & 1 & $\mathrm{~m}^{2}$ & \multicolumn{2}{|l|}{$31.5 \mathrm{~kg} / \mathrm{m}^{2}$} & \\
\hline $\begin{array}{l}\text { Transportation to site } \\
(20 \mathrm{~km})\end{array}$ & 630 & kgkm & $\begin{array}{l}\text { Transport, freight, lorry 16-32 metric ton, EUI } \\
\text { transport, freight, lorry 16-32 metric ton EURO3 }\end{array}$ & $\begin{array}{l}\text { RO3 (Row) } \\
\text { Alloc Rec, U }\end{array}$ & $\begin{array}{c}\text { Ecoinvent } \\
3\end{array}$ \\
\hline \multicolumn{6}{|c|}{ Scenario $100 \%$ of all materials go to landfill } \\
\hline Life end REC-A & \multicolumn{2}{|l|}{1} & $\mathrm{~m}^{2}$ & & \\
\hline Outputs & Amount & \multicolumn{2}{|r|}{ Data selection } & \multicolumn{2}{|c|}{ Database } \\
\hline Landfill lining & $100 \%$ & \multicolumn{2}{|c|}{$\begin{array}{l}\text { Waste cement in concrete and mortar (RoW) treatment of, } \\
\text { collection for final disposal Alloc Rec, } \mathrm{U}\end{array}$} & \multicolumn{2}{|c|}{ Ecoinvent 3} \\
\hline
\end{tabular}




\section{COATING B (REC-B)}

Information about materials obtaining for REC-B system and used in SIMAPRO software.

\begin{tabular}{|c|c|c|c|c|}
\hline $\begin{array}{l}\text { Materials obtaining } \\
\text { REC-B }\end{array}$ & 1 & $\mathrm{~m}^{2}$ & $11.52 \mathrm{~kg}$ & \\
\hline Inputs & Amount & Unit & Data selection & Database \\
\hline Clay & 9.09 & $\mathrm{~kg}$ & Clay (RoW) clay pit operation alloc Rec, $\mathrm{U}$ & Ecoinvent 3 \\
\hline Sand & 3.21175 & $\mathrm{~kg}$ & Sand (RoW) gravel and quarry operation A lloc Rec, U & Ecoinvent 3 \\
\hline Lime & 0.39 & $\mathrm{~kg}$ & Lime, hydrated, packed (GLO) market for Alloc Rec, U & Ecoinvent 3 \\
\hline $\begin{array}{l}\text { Agave Lechugilla } \\
\text { Fibber. }\end{array}$ & 0.13 & $\mathrm{~kg}$ & FIBER AGAVE LECHUGUILLA, (MX) U REC-B, REC-C & Creado \\
\hline Nopal Mucilage & 0.065 & $\mathrm{~kg}$ & MUCILAGO, CONSTRUCTION SITE (MX) U REC-B & Creado \\
\hline $\begin{array}{c}\text { Diesel (Backhoe loader) } \\
\text { for sand and clay } \\
\text { extraction }\end{array}$ & 0.002 & Ml & Energy, from diesel bumed in machinery/ RER Energy & Agri-footprint \\
\hline Water & 2 & $\mathrm{~kg}$ & $\begin{array}{c}\text { Tap water (RoW) tap water production, convectional treatment } \\
\text { Alloc Rec, } U\end{array}$ & Ecoinvent 3 \\
\hline
\end{tabular}

\begin{tabular}{|c|c|c|c|c|c|c|}
\hline $\begin{array}{c}\text { Transport MAT Production Place } \\
\text { REC-B }\end{array}$ & 1 & $\mathrm{~m}^{2}$ REC-B & & & & \\
\hline Inputs & $\begin{array}{c}\text { Amount } \\
(\mathrm{kg})\end{array}$ & $\begin{array}{l}\text { Distance } \\
(\mathrm{km})\end{array}$ & $\mathrm{t} \mathrm{km}$ & Capacity & Model Name & Database \\
\hline Clay Transport & 9.09 & 1250 & 0.11 & 4 ton & $\begin{array}{l}\text { Transport, freight, lorry 3.5-7.5 } \\
\text { metric ton, EURO3 (RER) transport, } \\
\text { freight, lorry 3.5-7.5 metric ton, } \\
\text { EURO3 Alloc Rec, U }\end{array}$ & Ecoinvent 3.0 \\
\hline Lime Transport & 0.39 & 8.00 & 0.00 & & $\begin{array}{l}\text { Transport, freight, lorry 3.5-7.5 } \\
\text { metric ton, EURO3 (RER) transport, } \\
\text { freight, lorry 3.5-7.5 metric ton, } \\
\text { EURO3 Alloc Rec, U }\end{array}$ & Ecoinvent 3.0 \\
\hline Sand Transport & 3.21 & 42.00 & 0.13 & 11 ton & $\begin{array}{l}\text { Transport, freight, lorry 3.5-7.5 } \\
\text { metric ton, EURO3 (RER) transport, } \\
\text { freight, lorry 3.5-7.5 metric ton, } \\
\text { EURO3 Alloc Rec, U }\end{array}$ & Ecoinvent 3.0 \\
\hline $\begin{array}{l}\text { Fiber and mucilage are extracted } \\
\text { close to the site and transported on } \\
\text { foot by wheelbarrow }\end{array}$ & & 0.25 & & & & \\
\hline
\end{tabular}

\begin{tabular}{|c|c|c|c|c|}
\hline Elaboration of REC-B & 1 & $\mathrm{~m}^{2}$ & & \\
\hline Inputs & Cantidad & Unidad & Conjunto de datos & $\begin{array}{c}\text { Base de } \\
\text { datos }\end{array}$ \\
\hline Material Transport $(0.12698 \mathrm{t})$ & 2516385 & $\mathrm{kgkm}$ & $\begin{array}{l}\text { Transport, freight, lomy 3.5-7.5 metric ton, } \\
\text { EURO3 (RER) transport, freight, lorry 3.5-7.5 } \\
\text { metric ton, EURO3 Alloc Rec, U }\end{array}$ & Ecoinvent 3 \\
\hline Pine wood 3th. Para andamios cualquier Nivel & 0.00012271 & $\mathrm{~m}^{3}$ & $\begin{array}{c}\text { Roundwood, Parana pine fro sustainable forest } \\
\text { management, under bark (RoW) softwood } \\
\text { forestry, Parana pine, sustainable forest } \\
\text { management Alloc Rec, U }\end{array}$ & Ecoinvent 3 \\
\hline
\end{tabular}

\begin{tabular}{|c|c|c|c|c|}
\hline Use REC-B (Flattened on wall 30 years) & 1 & $\mathrm{~m}^{2}$ & Data & Database \\
\hline Inputs & Amount & Unity & $11.52 \mathrm{~kg} / \mathrm{m}^{2}$ & \\
\hline $1 \mathrm{~m}^{2}$ recubrimiento & 1 & $\mathrm{~m}^{2}$ & $\begin{array}{c}\text { Transport, freight, lorry 16-32 metric ton, Euro3 } \\
\text { (RoW) transport, freight, lorry 16-32 metric ton, } \\
\text { EURO3 Alloc Rec, U }\end{array}$ & Ecoinvent 3 \\
\hline Transporte a sitio (20km) & 230.4 & $\mathrm{kgkm}$ & \begin{tabular}{c} 
EUR \\
\hline
\end{tabular}
\end{tabular}

\begin{tabular}{|c|c|c|c|c|}
\hline End of life REC-B & 1 & $\mathrm{~m}^{2}$ & & \\
\hline Outputs & \multicolumn{2}{|c|}{ amount } & Data selection & Database \\
\hline $1 \mathrm{~m}^{2}$ covering & \multicolumn{2}{|c|}{$100 \%$} & $\begin{array}{l}\text { Biowaste (Row) treatment of, composting Alloc } \\
\text { Rec, U }\end{array}$ & Ecoinvent 3 \\
\hline
\end{tabular}




\section{COATING C (REC-C)}

Information about materials obtaining for REC-C system and used in SIMAPRO software.

\begin{tabular}{|c|c|c|c|c|}
\hline $\begin{array}{l}\text { Materials obtaining } \\
\text { REC-C }\end{array}$ & 1 & $\mathrm{~m}^{2}$ & $11.52 \mathrm{~kg}$ & \\
\hline Inputs & Amount & Unit & Data selection & Database \\
\hline Clay & 9.09 & $\mathrm{~kg}$ & Clay (RoW) clay pit operation alloc Rec, U & Ecoinvent 3 \\
\hline Sand & 3.21175 & $\mathrm{~kg}$ & Sand (RoW) gravel and quarry operation Alloc Rec, U & Ecoinvent 3 \\
\hline Lime & 0.39 & $\mathrm{~kg}$ & Cement, Portland (US) production Alloc Rec, U & Ecoinvent 3 \\
\hline Fibber & 0.13 & $\mathrm{~kg}$ & FIBRA AGAVE LECHUGILLA, (MX) U REC-B, REC-C & Creado \\
\hline Nopal Mucilage & 0.065 & $\mathrm{~kg}$ & MUCÍAGO, EN SITIO EN CONSTRUCCIÓN (MX) U REC-C & Creado \\
\hline $\begin{array}{c}\text { Diesel (Backhoe loader) } \\
\text { for sand and clay } \\
\text { extraction. }\end{array}$ & 0.001 & MJ & Energy, from diesel burned in machinery / RER Energy & Agry-footprint \\
\hline Water (Natural) & 2 & $\mathrm{~kg}$ & Water, well, in-ground, $\mathrm{Mx}$ & Ecoinvent 3 \\
\hline
\end{tabular}

\begin{tabular}{|c|c|c|c|c|c|c|}
\hline $\begin{array}{c}\text { Transport MAT Production } \\
\text { Place REC-C } \\
\end{array}$ & 1 & $\mathrm{~m}^{2} \mathrm{REC}-\mathrm{C}$ & & & & \\
\hline Inputs & $\begin{array}{c}\text { Amount } \\
(\mathrm{kg})\end{array}$ & $\begin{array}{l}\text { Distance } \\
(\mathrm{km})\end{array}$ & $\mathrm{t} \mathrm{km}$ & Capacity & Model Name & Database \\
\hline $\begin{array}{l}\text { Clay transport (Taken from } \\
\text { the site where it is produced } \\
\text { with a wheelbarrow) }\end{array}$ & 0 & 0.00 & 0.00 & & & \\
\hline Lime transport & 0.39 & 2.00 & 0.00 & 4 ton & $\begin{array}{c}\text { Transport, freight, lorry } \\
\text { 3.5-7.5 metric ton, EURO3 } \\
\text { (RER) transport, freight, lorry } \\
\text { 3.5-7.5 metric ton, EURO3 } \\
\text { Alloc Rec, U }\end{array}$ & Ecoinvent 3.0 \\
\hline Sand Transport (Bank-Site) & 3.21 & 2.00 & 0.01 & 7 ton & $\begin{array}{c}\text { Transport, freight, lorry } \\
\text { 3.5-7.5 metric ton, EURO3 } \\
\text { (RER) transport, freight, lorry } \\
\text { 3.5-7.5 metric ton, EURO3 } \\
\text { Alloc Rec, U }\end{array}$ & Ecoinvent 3.0 \\
\hline \multicolumn{7}{|l|}{$\begin{array}{c}\text { Fiber and mucilage are } \\
\text { extracted close to the site } \\
\text { and transported on foot by } \\
\text { wheelbarrow }\end{array}$} \\
\hline & 3.60 & & 0.007 & & & \\
\hline
\end{tabular}

\begin{tabular}{|c|c|c|c|c|}
\hline Elaboration of REC-C & 1 & $\mathrm{~m}^{2}$ & & \\
\hline Inputs & Amount & Unit & Data selection & Database \\
\hline Materials transport $(0.003602 \mathrm{t})$ & 7.2035 & kgk m & $\begin{array}{c}\text { Transport, freight, lorry } 3.5-7.5 \text { metric ton, EURO3 } \\
\text { (RER) transport, freight, lorry 3.5-7.5 metric ton, } \\
\text { EURO3 Alloc Rec, } \mathrm{U}\end{array}$ & Ecoinvent 3 \\
\hline $\begin{array}{l}\text { Pinewood 3th for scaffolding } \\
\text { any Level }\end{array}$ & 0.00012271 & $\mathrm{~m}^{2}$ & $\begin{array}{c}\text { Roundwood, Parana pine fro sustainable forest } \\
\text { management, under bark (RoW) softwood forestry, } \\
\text { Parana pine, sustainable forest management Alloc } \\
\text { Rec, } \mathrm{U}\end{array}$ & Ecoinvent 3 \\
\hline
\end{tabular}

\begin{tabular}{|c|c|c|c|}
\hline $\begin{array}{c}\text { USE REC-C (Flattened on } \\
\text { wall 30 years) }\end{array}$ & 1 & $\mathrm{~m}^{2}$ & Transport is not considered \\
\hline Entradas & Cantidad & Unidad & Conjunto de datos \\
\hline $1 \mathrm{~m}^{2}$ covering & 1 & $\mathrm{~m}^{2}$ & \\
\hline
\end{tabular}

Escenario: $100 \%$ de todos los materiales se utilizan como composta para plantas

\begin{tabular}{|c|c|c|c|c|}
\hline Endo $f$ life REC-C & 1 & $\mathrm{~m}^{2}$ & Unit & Data selection \\
\hline Outputs & \multicolumn{2}{|c|}{ Amount } & Biowaste (Row) treatment of, composting Alloc Rec, $\mathrm{U}$ & Ecoinvent 3 \\
\hline $1 \mathrm{~m}^{2}$ covering & \multicolumn{2}{|c|}{$100 \%$} & & \\
\hline
\end{tabular}




\section{REFERENCES}

[1] Pandey, D.M. Agrawal and J. Pandey. "Carbon footprint: current methods of estimation." Environmental Monitoring and Assessment, Vol. 178 No1-4, pp. 135-160, 2010. https://doi.org/10.1007/s10661-010-1678-y

[2] Carballo, A., J.L. Doménech and M.C. García. "Eco-labelling based on the ecological and carbon footprint: a green marketing tool." IAU Sustainability, Vol. 3 No.7, pp. $1-2,2009$.

[3] IPCC Intergovernmental Panel On Climate Change, United Nations Environment Programme (UNEP) and the World Meteorological Organization (WMO) 2011. https://www.ipcc.ch

[6] SIM APRO "Analisis de Ciclo de Vida. Footprint analysis software". https://www.lavola.com/es/simapro/

[7] Kuitem M. "Setting the carbon footprint criteria for public construction projects." Science Direct, Elsevier, pp. 154-161. 2015

[8] https://www.gob.mx/cms/uploads/attachment/file/235891/ FACTORES_DE_EMISION_2015.pdf

[9] Filipus Priyo Suprobo, Ririn Dina Mutfianti, "Environmental Innovation Model with Product and Outcomes Dimension of Green Kampung in Surabaya City," Civil Engineering and Architecture, Vol. 9, No. 1, pp. 1 - 8, 2021. DOI: $10.13189 /$ cea.2021.090101.

[10] Rakhmawati, A. N., Devia, Y. P., \& Wijatmiko, I. Life Cycle Assessment (LCA.) Analysis Of Concrete Slab Construction For Estimating The Environmental Impact. Rekayasa Sipil, Vol. 14 No.3, pp. 232-237. 2020.

[11] Fulzele, V., \& Shankar, R. Performance measurement of sustainable freight transportation: a consensus model and FERA approach. Annals of Operations Research, pp. 1-42. 2021.

Quoc Gia Hoang, Quoc Vuong Vu, "Estimation the Initial Cement Dosage of Concrete from Mechanical Behavior and Chemical Analysis," Civil Engineering and Architecture, Vol. 8, No. 4, pp. 580 - 585, 2020. DOI: 10.13189/cea.2020.080422. NMX-SAA-14040. IMNC-2008 Environment Management-Life Cycle Analysis- Principles and frame of reference. Complexities. Information Technology Vol. 23 No. 1, pp 163-176. 2012.

[5] Mexican Standard IMNC ISO 14040:2006 